\title{
NYíRI Kristóf
}

\section{Konzervatív pedagógia a 21. században Ismeretmegőrzés, hálózott tudás, képi gondolkodás*}

Mindenekelőtt hadd köszönjem meg a konferencia szervezőinek, hogy felkértek e referátum megtartására. Külön hálás vagyok, amiért - elárulom - ugyanők témajavaslatokat is megfogalmaztak: beszéljek úgymond a konzervativizmusról, a tudásmegőrzésről, a tudáshálózatokról, a képiségről. A szervezők ismernek: tudják mivel foglalkozom. Például a konzervatív gondolkodással immár vagy negyven éve. ${ }^{1}$ Bő negyven évvel ezelőtt rádöbbentem, hogy jómagam valamiképp, így vagy úgy, konzervatív beállítottságú vagyok, s azóta újra meg újra kísérletet teszek arra, hogy kidolgozzak egyfajta ténylegesen a konzervatív lelki alkatnak megfelelő filozófiát. Arra az elméletileg egyáltalán nem egyszerű kérdésre, hogy ugyan mit is őriz a konzervatív, ma úgy válaszolnék, hogy a konzervatív a jövőt őrzi, közelebbről azt a tudásteljességet, amely a jövő nemzedékek életlehetőségei megteremtéséhez szükséges. Az így fölfogott konzervatív program tehát eleve pedagógiai program. És az így fölfogott konzervatizmus - hadd használjam a szó rövidebb alakját - alapvetően politikasemleges, tudniillik abban az értelemben, hogy nem helyezhető el a baloldaljobboldal skálán. ${ }^{2}$ Annyiban persze nem politikasemleges, hogy éppenséggel szembeszegül bármiféle tudásterrorral, a többség tudásterrorjával a kisebbség fölött, és a kisebbség tudásterrorjával a többség fölött. A konzervatizmus az öntörvényű, decentralizált tudás szószólója.

A decentralizált tudás fogalma nem mentes egy és más paradoxontól, mint ahogyan a konzervatizmust általában is paradoxonok övezik. Ezeket referátumomban érzékeltetni fogom. Mondandómat négy pontban foglalom össze. A konzervatizmus paradoxonait mindjárt az első pontban érintem. Egyfajta föloldásukra a második pontban a tudáskonzervatizmus gondolatának bevezetésével teszek kísérletet. A harmadik pont taglalja a decentralizált és ezáltal persze fragmentált tudás problematikáját. Ebben a pontban egyfelől a hálózott tudás kérdésével, másfelől a gyakorlati tudás és az elméleti tudás viszonyával illetve készségek és tartalmi tudás kapcsolatával is igyekszem szembenézni, nem függetlenül egy friss olvasmányélményemtől, nevezetesen E. D. Hirsch, Jr. most szeptemberben megjelent könyvétől: Why Knowledge Matters: Rescuing Our Children from Failed Educational Theories. ${ }^{3}$ Végül közeledve a negyedik pont felé, melynek a "Vizuális ott-

\footnotetext{
* A Magyar Pedagógiai Társaság és a BME Tanárképző Központ által „A PEDAGÓGIA ÚJ DIMENZIÓı” címmel az MPT 125 éves fennállása alkalmából rendezett konferencián 2016. november 29-ikén elhangzott előadás jegyzetekkel bővített szövege.

${ }^{1}$ Ld. „Wittgenstein új tradicionalizmusa” c. írásomat, Világosság 1975/10, 627-629. o., vagy Id. később pl. a „Konzervatív antropológia: Az ifjabb Wittgenstein” fejezetet Európa szélén c. kötetemben, Budapest: Kossuth Könyvkiadó, 1986.

2 Vö. Kieron O’Hara, Conservatism, London: Reaktion Books, 2011, 207. o. és 210. o.

${ }^{3}$ Cambridge, MA: Harvard Education Press, 2016.
} 
honosság" címet adtam, a fragmentálódó tudás valósága és az egészleges tudás eszménye közötti feszültséget azáltal törekszem enyhíteni, hogy rámutatok a szónyelvi keretezettséget nyilván igénylő, ám gondolkodásunkban mégis elsődleges képi dimenzió diszciplínákatáthidaló voltára.

\section{A konzervatizmus paradoxonai}

A konzervatív lelki alkat fogalma, melyet bevezetőmben alkalmaztam, egy ideje már polgárjoggal bír az empirikus pszichológiában. Noha a „konzervatizmus” kifejezés, és párja, a „liberalizmus”, politikatörténetileg alig kétszáz éves múltra tekinthet vissza, konzervatizmusról és liberalizmusról mint általános beállítottságról úgyszólván örök emberi vonásokként beszélhetünk. A liberálishoz képest a konzervatív kevésbé nyitott az új tapasztalatok iránt, nehezebben viseli az egyértelműség hiányát; igényli a rendet, az átlátható alakzatot - rajzban, festményben, zenében is. Állandóságra vágyik a változás helyett, egyszerűségre az összetettel szemben, kerüli az ismeretlent és maradna a megszokottnál, inkább szabálykövető semmint kreatív, inkább hűséges semmint lázadó. - Ezt a felsorolást érzékelhetően liberális szerzőtől vettem át, ${ }^{4}$ a képletek azonban a magam konzervatív nézőpontjából is helytállónak tűnnek, bár aligha túlontúl emelkedettnek. Persze mindenkori filozófiai vezércsillagom, az igencsak konzervatív Wittgenstein is meglehetősen földhözragadt hasonlatot használt, amikor pedagógiai alapelvét így fogalmazta meg: „Ha azt mondod egy gyereknek, hogy NEM, olyan legyél, mint a fal, nem pedig mint egy ajtó."5 Jómagam hadd ne riadjak vissza magasztosabb formuláktól. A konzervatív, mondanám, alázatot érez a teremtett vagy keletkezett világ iránt, valamiféle kötelességtudat vezérli. Jogokra akkor tart igényt, ha kiküzdötte és hite szerint kiérdemelte azokat. A konzervatív kétségkívül a késleltetett jutalmazás híve.

Az írott történelem korai szakaszaiban - és az iratlan történelem során méginkább, erre mindjárt visszatérek - a konzervatív beállítottság uralkodó volt, míg a liberális kivételes és üldözött. Ehhez képest késő-modern világunkban a konzervatív lelki alkat nemcsak visszaszorulóban van, de többé-kevésbé el is vesztette kapcsolatát a tényleges élettel. Ahhoz, hogy érzékenységét a valóság történései iránt helyreállítsa, a konzervatív lelki alkatnak a jelent hitelesen értelmező elméletre kellene szert tennie. Ez az elmélet nemigen lehet más, mint valamiféle liberális konzervatizmus. Mármost a lelki beállítottság szintjén a konzervatizmus a liberalizmussal nem ötvözhető. Ötvözhető-e elméleti szinten? A huszadik század meghatározó liberális konzervatív gondolkodója Friedrich August von Hayek. Ám vajon megbízható kalauzunk-e az idős Hayek, midőn így ír: „Nem azáltal tartjuk fenn a

\footnotetext{
${ }^{4}$ John T. Jost, „The End of the End of Ideology”, American Psychologist, 61. évf., 7. sz. (2006. okt.), 651-670. o. - Néhány későbbi jelentős írás: James H. Fowler - Darren Schreiber, „Biology, Politics, and the Emerging Science of Human Nature", Science 322 (2008. nov. 7.), 912-914. o.; Peter K. Hatemi - Rose McDermott, „The Genetics of Politics: Discovery, Challenges, and Progress", Trends in Genetics, 28. évf., 10. sz. (2012. okt.), 525533. o.; J. R. Hibbing - K. B. Smith - J. R. Alford, „Differences in Negativity Bias Underlie Variations in Political Ideology" (tanulmány, azt követő vitával), Behavioral and Brain Sciences 37 (2014), 297-350. o.

${ }^{5}$ K. E. Tranøy, „Wittgenstein in Cambridge 1949-51: Some Personal Recollections”, Essays on Wittgenstein in Honour of G. H. von Wright-Acta Philosophica Fennica 28/1-3 (1976), 15 . o.
} 
civilizációt, hogy megadjuk 'az egyenlő gondoskodás és tisztelet jogát' azoknak, akik megszegik a szabályokat. És az sem szolgálhatja társadalmunk fenntartását, ha minden olyan erkölcsi hitet, amelyet egyenlő meggyőződéssel vallanak, egyformán legitimnek fogadunk el... Az tesz valakit társadalmunk tagjává, azáltal lehetnek követelései, ha engedelmeskedik ezen társadalom szabályainak. Egészen ellentétes nézetek jogokat adhatnak neki más társadalmakban, de nem a miénkben. Az antropológia tudománya számára minden kultúra és erkölcs egyformán jó lehet, de a magunk társadalmát azáltal tartjuk fenn, hogy többre értékeljük más társadalmaknál." ${ }^{6}$ - A vizuális tanulás területének egyik kimagasló huszadik századi szakértője a művészetpszichológus Rudolf Arnheim. Társadalomfelfogását tekintve Arnheim merőben konzervatív, miközben múkritikusként vagy jelesül a gyermekrajz elméletének megújítójaként éppenséggel avantgárd nézeteket képvisel. Ám vajon megbízható kalauzunk-e Arnheim, amikor azt fejtegeti, hogy a lineáris perspektíva és naturalista ábrázolás szabályait nem követő korai gyermekmúvész mélyebben realista lehet, mint lesz majd serdülőként, ama szabályokat elsajátítva és alkalmazva? ${ }^{7}$ - A common-sense ismeretfilozófiai realizmus briliáns kortárs alakja az amerikai filozófusnő Susan Haack. A common-sense realizmus és a konzervatív világfelfogás egymást feltételező látásmódok, erre referátumom harmadik pontjában még visszatérek. Haack önmagát feministának, éspedig régimódi feministának mondja, régimódinak, mivel noha a női egyenjogúság elkötelezett harcosa, semmit sem tud kezdeni az úgymond „női szempontú” vagy „gender" szempontú tudás relativista-társadalomkonstruktivista eszméivel. ${ }^{8}$ Ám vajon megbízható kalauzunk-e Haack, midőn ama hitelesen időszerű liberális konzervatizmust keressük?

És akkor itt kanyarodom vissza a bevezetőmben feltett „mit őriz a konzervatív?” kérdéshez. $A z$ általam ma lehetségesnek tartott választ ott a bevezetőben - ha még emlékeznek nyomban meg is fogalmaztam, a választ referátumom következő pontjában még részletezem, előbb azonban most azt kell világossá tennem, hogy a konzervatizmus mibenlétére vonatkozó szokásos formulák a huszonegyedik században immár miért használhatatlanok. Mert mit is őriz a konzervatív? Ha azt mondjuk, hogy a konzervatív a fennállót őrzi, vagyis a mindenkori éppen adott jelent, akkor elfogadjuk, hogy a konzervatizmus hol ilyen, hol olyan normákat képvisel - azaz bármit. Ha ellenben a konzervatizmust úgy tekintjük, mint amely ezt vagy azt az elmúlt világot törekszik újrateremteni, akkor indoklásra szorul, hogy vajon miért éppen ezekhez vagy azokhoz a korábbi időkhöz kellene visszatérnünk? Az effajta indoklás csak hamis varázslat lehet: valami képzelt aranykor felidézése. Példát mondok: képzelt múltbeli világ az az eszményített nemzetállami Európa, amelyet a

\footnotetext{
${ }^{6}$ F. A. von Hayek, Law, Legislation and Liberty, 3. köt., London: Routledge \& Kegan Paul, 1979, 172. o.

7 Vö. Arnheim, A vizuális élmény: Az alkotó látás pszichológiája, Budapest: Gondolat, 1979, Id. a 99-126. oldalakat (eredetileg: Rudolf Arnheim, Art and Visual Perception: A Psychology of the Creative Eye, Berkeley: University of California Press, 1954, második, bővített és módosított kiadás: 1974, a fordítást ennek alapján készítette Szili József és Tellér Gyula); ill. Id. még különösen: Rudolf Arnheim, „Visual Thinking”, a Kepes György által szerkesztett Education of Vision c. kötetben, New York: Braziller, 1965.

${ }^{8}$ Ld. Haack „Reflections on Relativism: From Momentous Tautology to Seductive Contradiction” c. tanulmányát Manifesto of a Passionate Moderate: Unfashionable Essays c. kötetében, Chicago: The University of Chicago Press, 1998; Id. még Haack, Reintegrating Philosophy, Heidelberg: Springer, 2016.
} 
mostanában sűrűn Budapestre látogató angol konzervatív filozófus Roger Scruton ajánl a föderatív Európa helyébe. Végül ha a konzervatizmust úgymond a hagyományok tiszteletével azonosítjuk - ez a konzervatizmus leggyakoribb értelmezése -, akkor beleütközünk abba a tudományosan mindenoldalúan igazolt történeti ténybe, hogy a szó pontos jelentésében a hagyomány éppenséggel szájhagyomány, tudniillik az írásbeliség-előtti kultúrák tudásátadó intézménye. Nyilván paradoxonhoz vezet, ha a nyomtatott könyv és a digitális dokumentumok korában olyan elméletet hirdetünk, amely a korai szóbeliség viszonyait föltételezi.

\section{Tudáskonzervatizmus}

A nyomtatott könyv és a digitális dokumentumok korát említettem, és mielőtt továbblépnék, hadd rögzítsem, hogy ebben a korban bármiféle felelős pedagógiának, s persze magától értetődően a konzervatív pedagógiának, bátorítania kell a papíralapú írást-olvasást, bátorítania könyvek, folyóiratok, újságok kézbevételét, különösen pedig printoutok készítését és használatát. A papírpazarlás mérséklése, az erdők védelme nyilvánvaló konzervatív feladat, de bizony védelmet érdemelnek az információ erdejében útjukat keresők is, akiket figyelmeztetnünk kell arra, hogy a képernyőről olvasás és képernyőre írás csak egészen rövid szövegek esetén teszi lehetővé a koherens fogalmazást és koherens befogadást. $A$ világháló mára az emberi tudás korábban elképzelhetetlen gazdagságú tárházává lett, ám ahhoz, hogy digitális szöveges tartalmakat kognitív veszteség nélkül hasznosíthassunk, azok hardcopy változatait is magunk elé kell tudnunk helyezni.

Visszatérve a konzervatizmus paradoxonaira, megoldási javaslatom tehát ez volt: amit a konzervatív őriz, az a történelem során felhalmozódott tudásteljesség. Tudásteljesség, amely nélkül a jövő nemzedékek életlehetőségei bizonytalanná lesznek. A konzervatív nem a múltba, hanem a jövőbe tekint, más-más korszakokban azonban, szükségképpen, más-más módon törekszik a jövő megőrzésére. Az írásbeliség-előtti és könyvnyomtatás-előtti mozdulatlannak látszó korban a konzervatív nyilván azon igyekezett, hogy gyermekei éppen úgy nőjenek fel, ahogyan az ő szülei felnőttek. Ez volt tehát a hagyományok, a kötelező kötöttségek kora. A nyomtatott könyvek egyéni tájékozódást lehetővé tevő modern világában a konzervatív a hamis eszmék keltette radikális változásoktól féltette a következő nemzedéket, innen a klasszikus konzervatizmus elmélet-ellenessége és a lassú-megfontolt haladás szorgalmazása. Végül a mai elektronikus, hálózott korban a konzervatív aggodalom elsősorban az olyannyira összetetté vált világ szélsőségesen kiszámíthatatlan voltának szól: a konzervatizmusnak ma éppenséggel nem elméletellenesnek kell lennie, hanem - az ismeretlen jövő veszélyeire felkészülendő - a tudás és tudomány elérhető teljességét kell követelnie. A tudásteljesség elválaszthatalan az egységes, egészleges tudás, a tudásegész eszményétől, mely azonban ellentmondani látszik a decentralizált és ezáltal fragmentált tudás bevezetőmben említett alapvető konzervatív eszményének. Feloldható-e ez az ellentmondás? 


\section{Decentralizált tudás}

Ha a konzervatizmus az emberi tudás teljessége megőrzésének programját jelenti, akkor abból kell kiindulnia, hogy tudásunk valóban tudás, azaz nem önkényes konstrukció, hanem a létező világról szól. A konzervatizmus, mint fentebb utaltam rá, a filozófiai realizmus talaján áll. A filozófiai realizmus tisztában van azzal, hogy az egyes ember tudása igencsak részleges, és hogy ki-ki a világot nagyon más szemszögből látja, nagyon eltérő módon fogja fel. Ettől azonban a világ még az, ami: összefüggő egységes egész, s a rá vonatkozó különböző igazságok egyetlen igazságrendszerré állhatnak össze. Vagyis a tudásegész eszményének a fragmentált s jelesül a decentralizált tudás jelensége valójában nem mond ellent. És akkor vessünk most egy pillantást a tudást éppen a tudás természetéből következően decentralizáltnak bemutató konzervatív érvelésre. A tizennyolcadik századtól a huszadik századig, Burke-től Wittgensteinig, a fentebb már idézett Hayekig, Polányi Mihályig és Thomas Kuhnig a konzervatív gondolkodás a tudást gyakorlatinak, lokálisnak, a tudást hordozó emberek között elosztottnak tartja. A tudás nem központosítható, mivel nem különíthető el azoktól a helyzetbe-ágyazott cselekvési mintázatoktól, amelyeket ki-ki személyes gyakorlata során megtestesít. Nem pusztán arról van szó, hogy az egyes emberek, az egyes tájak lakói, az egyes foglalkozások múvelői bármiféle központi hatalomnál jobban tudják, mi is az érdekük: hanem arról, hogy ez a tudás összefonódik életük minden zsigeri rezdülésével, attól nem elválasztható.

Vagyis a konzervatív érvelés szerint tudásunknak óhatatlanul van helyi dimenziója és egyszersmind gyakorlati dimenziója is: nincsen elméleti tudás - knowing that, ahogyan Ryle nyomán mondjuk ${ }^{9}$ - gyakorlati tudás, knowing how nélkül. Még a matematikai elmélet is gyakorlati tudásra alapozódik, a számolás arra, ahogyan ujjainkat használjuk vagy kavicsokat mozgatunk, az algebra arra a készségre, ahogyan szimbólumokat helyezünk át papíron vagy éppen vizuális képzeletünkben. A „készség” szót használtam, s ezzel persze pedagógiai darázsfészekbe nyúlok. Szeretném tisztázni: abból a konzervatív álláspontból, hogy nincsen elméleti tudás gyakorlati készségek nélkül, egyáltalán nem következik a ma divatos tétel, miszerint nem tartalmakat kell tanítanunk, hanem készségeket, sőt éppenséggel általános készségeket: a kritikai gondolkodás, a kreatív gondolkodás és a problémamegoldás készségeit. A bevezetőmben említett E. D. Hirsch friss összehasonlító adatokkal és számos szakirodalmi hivatkozással bizonyítja, hogy az általános készségek eszméjére alapozó iskola csődöt mond, hogy nincsen kognitív készség kognitív tartalmak nélkül, magyarán, hogy ismereteket kell tanítanunk.

Hadd tegyek ehhez két megjegyzést. Az első: visszautalás a világhálóra. A második: utalás a kánon fogalmára. Akkor tehát az első, és részben itt is támaszkodom Hirschre: tévedünk, ha azt gondoljuk, hogy ismereteket fölösleges bemagoltatnunk, hiszen úgymond azok ott találhatók az interneten, mindössze keresni kell tudni. Szögezzük le ezzel szemben: hatékonyan keresni valójában az képes, aki valamennyire már ért ahhoz, amire rákérdez.

\footnotetext{
${ }^{9}$ Gilbert Ryle, A szellem fogalma, ford. Altrichter Ferenc, Budapest: Gondolat, 1974.
} 
Továbbá világos, hogy az új ismeretek áradatában csak az igazodik el, aki meglévő ismereteihez kötheti azokat. Még a hálózat fogalmánál maradva: a Finn példa címú, mindnyájunk által ismert könyv ${ }^{10}$ újra meg újra hangsúlyozza, hogy bizony lehetséges minőségi oktatást folytatni központosított irányítás és ellenőrzés nélkül is, ha szabad iskolák és jólképzett tanárok mintegy kapcsok és csomópontok rendszerén át áramoltatják kölcsönös észrevételeiket. A kánont, a tudás egyfajta megállapodott egységét, az eleven hálózat segít fenntartani.

Az emberi tudás összefüggésrendszere maga is hálót alkot, éspedig olyan hálót, amelyben bizonyos tudástartalmakhoz, mintegy a tudásháló tengelypontjaihoz, különösen sok kapocs vezet. Ezeket a tartalmakat mostanára egyre gyakrabban nemcsak szövegek, hanem képek, sőt mozgóképek alkotják. A verbális tudás szegmensei között ma egyre inkább vizuális tartalmak teremtenek kapcsolatot. Egyfajta vizuális hazatérésnek vagyunk tanúi.

\section{Vizuális otthonosság}

Az emberi gondolkodás elsődlegesen képies, és csak másodlagosan szóbeli. Az írásbeliség és könyvnyomtatás évezredei-évszázadai nem kedveztek a képi tudásközvetítésnek, viszont a digitális közeg az őseredeti képi dimenziót ismét az emberi életvilág természetes részévé teszi. Jelen referátumom a képiségre a konzervatizmus szemszögéből tekint; a képprobléma általánosabb körüljárására Benedek professzor úrral közösen a BME MPT Képi Tanulás Múhelye keretében sok esztendeje törekszünk, ${ }^{11}$ e törekvések egyfajta summázatát adja „Elfelejtett képelméletek” című szakirodalmi áttekintésem. ${ }^{12}$

Következzen tehát néhány egészen rövid, befejező utalás konzervatizmus és képiség kapcsolatáról. Először is belátható, hogy a kép a konzervatív nézőpontból oly alapvető gyakorlati tudás átadásának jóval alkalmasabb eszköze, mint a pusztán szóbeli közlés. Másodszor nyilvánvaló, hogy a kép nemcsak konzervatív abban az értelemben, hogy adott elképzelést, alakot, ősi vagy újabb tudást változhatatlan helyzetben és tartalommal rögzít, de egyszersmind radikális igazsághordozó is. Az összes vonatkozó technikai találmány dacára még mindig úgy áll a helyzet, hogy képekkel hazudni jóval körülményesebb, mint szavakkal.

\footnotetext{
10 Pasi Sahlberg könyvét Fazekas Dóra fordításában a Nemzedékek Tudása Tankönyvkiadó jelentette meg Budapesten 2013-ban

112010 ősze óta évi rendszerességgel megrendezett Visual Learning konferenciasorozatunk nyomán eddig a következő - válogatott, szigorúan szakmailag lektorált és szerkesztett - kötetek jelentek meg: Benedek András - Nyíri Kristóf (szerk.), Images in Language: Metaphors and Metamorphoses (Visual Learning sorozat, 1. köt.), Frankfurt/M.: Peter Lang, 2011; Benedek András - Nyíri Kristóf (szerk.), The Iconic Turn in Education (Visual Learning sorozat, 2. köt.), Frankfurt/M.: Peter Lang, 2012; Benedek András - Nyíri Kristóf (szerk.), How to Do Things with Pictures: Skill, Practice, Performance (Visual Learning sorozat, 3. köt.), Frankfurt/M.: Peter Lang Edition, 2013; Benedek András - Nyíri Kristóf (szerk.), The Power of the Image: Emotion, Expression, Explanation (Visual Learning sorozat, 4. köt.), Frankfurt/M.: Peter Lang Edition, 2014; Benedek András - Nyíri Kristóf (szerk.), Beyond Words: Pictures, Parables, Paradoxes (Visual Learning sorozat, 5. köt.), Frankfurt/M.: Peter Lang Edition, 2015; Benedek András - Veszelszki Ágnes (szerk.), In the Beginning was the Image: The Omnipresence of Pictures: Time, Truth, Tradition (Visual Learning sorozat, 6. köt.), Frankfurt/M.: Peter Lang Edition, 2016.

12 A Benedek András és Nyíri Kristóf által szerkesztett Képi Tanulás Múhelye Füzetek sorozat 2016/3-as számában. Online: https://www.academia.edu/29571702/Forgotten_Theories_of_the_Image_in_Hungarian.
} 
Harmadszor a mai konzervatív számára különös jelentősége van a mozgóképnek, nemcsak mint életeleven ábrázolásnak, hanem kiváltképpen mint az ismeretlen jövőt próbaképpen megjelenítő animációnak-szimulációnak. Negyedszer a képek köny-nyebb teremthetősége és elérhetősége filozófiai szinten megoldást kínál arra a fentebb már érintett problémára, hogy a mai konzervatív vajon hogyan boldoguljon a hagyományok hagyományos konzervatív dilemmájával. A szavak közegében a hangzó hagyomány a megfellebbezhetetlen tekintély erejére támaszkodva adhatott át felfogásmódokat, az írásban rögzített szövegek is tekintélyt parancsoltak és nem vagy csak nehezen voltak ellenőrizhetők. A képek közegében azonban közvetlenül megmutatkozik az, hogy milyen maga a világ ténylegesen. A tekintély vak hatalma helyébe a látható világ ereje lép. A hagyományok nélküli konzervatizmus - a huszonegyedik század konzervatizmusa - a szavak rábeszélő képessége helyett, és a szövegesracionális érvelés mellett, a kognitív architektúránkban eleve megalapozott képi realizmus igazságaira hagyatkozik.

A Magyar Pedagógiai Társaság ünnepi konferenciáján jelen referátumom szövegét nem szabadon mondtam el, hanem felolvastam, és így az előadást persze nehezebb volt követni. Most azonban immár íme itt olvasható, jegyzetekkel ellátva, az Opus et Educatio lapjain. (Továbbá az academia.edu-n megtalálható két hasonló témájú prezentációm is, melyeket 2016 májusában az ELTE-n tartottam. Az egyik „Képiség mint konzervatív elv” címmel a Tanító és Óvóképző Karon, a másik „A konzervatív tudásfogalom” címmel a Pedagógiai és Pszichológiai Karon hangzott el.) - Mielőtt azonban megköszönném figyelmüket, tartozom még három kérdés megválaszolásával. Ezeket referátumom első pontjában tettem fel, talán esetlegesen. Igaza van-e Hayeknak, amikor úgy véli, hogy a magunk társadalmát fönntartandó, azt többre kell értékelnünk más társadalmaknál? Válaszom: ha globalizálódó világunkban olyan társadalmakkal találkozunk, amelyek tapasztalataiból éppenséggel tanulhatunk, akkor ezeket a tanulságokat nem elutasítanunk, hanem átvennünk kell. Igaza van-e Arnheimnak, amikor a gyermekrajz különösségeiben egyfajta sajátos realizmust pillant meg? Válaszom: a valóság sokféle nézőpontból történő ábrázolása hozzáad ismereteinkhez, a stíluseszközök változatossága megőrzendő vívmány, ${ }^{13}$ de a lineáris perspektíva kiválóan alkalmas megfeleltetési technika, amelynek jelentőségét nem tehetjük viszonylagossá. Igaza van-e Susan Haacknak, amikor elutasítja a tudás gender-szempontú megközelítését? Válaszom: a társadalmi nem fogalma olyan elgondolás, amelynek révén kultúránkról a korábbinál radikálisan helyénvalóbb tudást alkothatunk, tudást, melyet a konzervatív pedagógiának nyilvánvalóan üdvözölnie és közvetítenie kell. A társadalmi nem: társadalmi konstrukció. Ezt a konstrukciót azonban elvileg teljes tudományos objektivitással írhatjuk le. Konzervatív nézőpontból, legyen konzervatizmusunk bármily liberális, a gender-elmélet semmiféle ismeretfilozófiai relativizmust nem alapoz meg.

A tanulmány elkészítését a Magyar Tudományos Akadémia Tantárgypedagógiai Kutatási Programja támogatta.

\footnotetext{
${ }^{13}$ Vö. pl. Howard Gardner, Artful Scribbles: The Significance of Children's Drawings, Basic Books, 1980, 72. o.
} 